\title{
FORMATION OF STAGHORN CALCULI AND THEIR SURGICAL IMPLICATIONS IN PARAPLEGICS AND TETRAPLEGICS
}

\author{
By Dr H. KRACHT and Professor Dr H.-K. BüsCHER \\ Department of Urology, Friederikenstift, Hannover, West Germany
}

THE prevention of complications of the urogenital system is an important prerequisite for the successful rehabilitation of a paraplegic patient. More important, the patient's life itself often depends on the preservation of renal function (Gibbon et al., 1969). The idea is to avoid urinary tract infections in patients with complete and incomplete paraplegia and tetraplegia, therefore it is necessary to break the vicious circle of residual urine-infection-reflux-stone formation (Büscher, I966). Under optimal conditions, about 70 per cent of these generally young patients can again become capable of earning their own living (Guttmann, 1966).

\section{CLINICAL FEATURES}

Until I970, we abserved a total of 29 patients who had become paralysed as a result of spinal cord injury (23 paraplegics and six tetraplegics) and who had staghorn calculi (Table I). This was about eight per cent of the total number of paraplegics treated by us. All but one of the 29 had been previously treated elsewhere and were transferred to us. All had a severe mixed infection of the urinary tract upon admission. Bacterium proteus was present in all urine cultures. An indwelling catheter was inserted in all patients at the beginning of the treatment.

\section{TABLE I}

General summary

Number of patients

Complete/incomplete paraplegia

Previous treatment elsewhere

Average age

Indwelling catheter:

immediately

Later, continually

Later, occasionally

Later, without catheter

Urinary infection (mixed infections; Bacterium proteus present in all specimens)

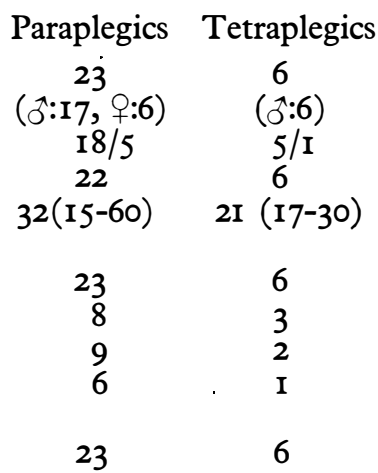

Table II shows the distribution of all stones found in this group of patients with regard to their location (left or right side) and organ site, as well as the average length of time which had elapsed between the paralysis-causing accident and the discovery of the stones; staghorn calculi were observed after an average of four years in the paraplegics and after one and a half years in the tetraplegics. 


\section{TABLE II}

Organ distribution and lateral location of all calculi observed in 29 paralysed patients, and length of time elapsed between the disabling accident and diagnosis of the stones

\section{Bladder stones}

Number of patients

Diagnosed after

Indwelling catheter at time of discovery

Stones in the ureter

Number of patients

Diagnosed after

\section{Calyx stones}

Number of patients

Diagnosed after

Renal pelvis stones

Number of patients

Diagnosed after

Staghorn calculi

Number of patients

Diagnosed after
Paraplegics

9

$\sim$ I7 months

8

$$
\begin{gathered}
\text { (right } \\
\text { 4, left I) } \\
\sim \text { I year }
\end{gathered}
$$

\section{8}

(right 3 , left 3 , bilat. 2)

$\sim 3$ years

I2

(right 3 , left 6 , bilat. 3)

$\sim 2$ years

23

(right Io, left 9, bilat. 4)

$\sim 4$ years
Tetraplegics

3

$\sim 6$ months

3

I

(right I)

$\sim 3$ months

$$
\begin{gathered}
\text { (right I, left I) } \\
\sim \text { I year }
\end{gathered}
$$

$$
\begin{gathered}
\text { (right }{ }^{4} \text {, bilat. I) } \\
\sim \text { I year }
\end{gathered}
$$

\section{6}

(right 4 , left I, bilat. I)

$\sim \mathrm{I} \frac{1}{2}$ years

\section{TABLE III}

Type and number of operations and average length of time elapsed since diagnosis of a staghorn calculus and since the disabling accident

Type of surgery

\section{Nephrectomy}

Number of patients

Time elapsed after diagnosis of a staghorn calculus

Time elapsed since accident

\section{Nephrostomy}

Number of patients

Time elapsed after diagnosis of a staghorn calculus

Time elapsed since accident

\section{Pyelotomy}

Number of patients

Time elapsed after diagnosis of a staghorn calculus

Time elapsed since accident
Paraplegics

$$
\begin{aligned}
& 7 \\
& \sim \text { I year } \\
& \sim 5 \text { years }
\end{aligned}
$$

I

I year

$3 \frac{3}{4}$ years

2

operated immediately

$\mathrm{I} \frac{1}{2}$ and Io years
Tetraplegics

3

$\sim \mathrm{I} \frac{1}{2}$ years

$\sim 3 \frac{1}{2}$ years

\section{I}

$\mathrm{I} \frac{1}{2}$ years

$2 \frac{1}{4}$ years

none 
Surgery was performed on ten of the paraplegics and on five of the tetraplegics (Table III). In the majority of these cases it was impossible to preserve the kidney, and nephrectomy was performed. All of the patients survived the operation, but post-operative improvement of the urinary tract infection occurred only in the nephrectomised patients (Table IV). Of the patients who underwent surgery without nephrectomy, stones recurred in all of the paraplegics but not in the one tetraplegic. Six of the paraplegics died on average four years after their

\section{TABLE IV}

\section{Course of illness}

Post-surgical improvement of infection

Number of patients

Recurrence of renal calculi

Number of patients

Location: same side opposite side

\section{Paraplegics Tetraplegics}

(all after nephrectomy) ${ }^{3}$

$3\left(\stackrel{5}{\sim}{ }^{1} \frac{1}{4}\right.$ years later $)$

2 ( $\mathrm{I} \frac{1}{2}$ and 5 years later)

Renal insufficiency

Number of patients

Years after accident

$\begin{aligned} & 7 \\ \sim & 6 \text { years }\end{aligned}$

none

Urine-bound substances in serum occasionally increased

Number of patients

2

$\mathrm{I} \frac{1}{2}$ and 2 years

6

$\sim 4$ years

$\sim 2 \frac{1}{4}$ years

$\sim$ I year

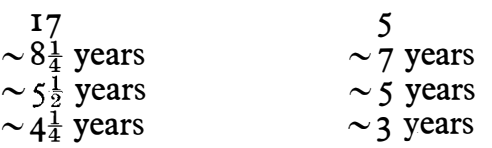

accident, but 17 were still alive on average eight years later. Of the tetraplegic patients with staghorn calculi, one died after four years, but the rest were still alive on average seven years later.

\section{DISCUSSION}

Chronic Urinary Infection and Reflux. During World War I, 80 per cent of all paraplegics died within a few weeks as a result of septic uremia and decubitus ulcers; only ten per cent survived for more than a year (Kaufmann \& Götze, 1968). In 1961, Comarr reported that complications in the form of urinary tract infections occurred in 90 per cent of his patients with transverse spinal cord lesions and that pyelonephritis was the most common cause of death, accounting 
for 64 per cent of the fatalities. According to Bors (1957), renal complications were the cause of death in 4.5 per cent of the patients two years after the initial injury, in 26 per cent after five years, in 48.6 per cent after ten years, and in 60 per cent of those who died more than ten years later.

The 'no-touch' technique of intermittent catheterisation was introduced by Guttmann (1965, I966) and has become the method of choice in the early treatment of the paralysed bladder. This method has produced considerably better results not only in the early treatment but also in the handling of the complications which almost always occur later on; such results have not been achieved with the primary indwelling catheter treatment (Comarr, I96I; Comarr et al., I962; Kollwitz, I963).

According to a survey made by Guttmann and Frankel (I966), 62.2 per cent of a total of 476 patients had sterile urine at the time of their discharge from the hospital. A supplementary work by Frankel (1969) reported that 82 per cent of male paraplegics had sterile urine at the time of their hospital discharge, as opposed to 92 per cent upon admission. A well-known German centre for the treatment of spinal injuries recently reported that over 50 per cent of all new admissions arrived with a bacterial infection of the urinary bladder. In spite of months of rigorous long-term therapy, they were unsuccessful in attaining a complete and lasting cure in any of these patients. Several of the patients who were admitted with sterile urine left the treatment centre with chronically-recurring urinary tract inflammations (Kaufmann \& Götze, 1968; Stoephasisus, 1970). Clearance tests were used to demonstrate that a chronic urinary tract infection is always a manifestation of pyelonephritis and that, in the presence of an infection, the renal function increasingly diminishes, depending on the amount of time elapsed since the spinal cord was damaged.

Renal insufficiency occurs even sooner when vesico-renal reflux is also present (Marchetti \& Gonick, I970). Ureterovesical or ureterovesico-renal reflux is often seen early in the course of illness in paraplegics and can quickly lead to virtually irreparable pyelonephritis (Büscher, 1966; Britten \& Ruedas, 1970). The cause of such reflux is, in most cases, a severe urinary tract infection which produces inflammatory changes in the bladder wall, including atonicity and thinning of the wall and the formation of diverticula (Büscher \& Federschmidt, I966; Guttmann, 1966). Ureterovesical reflux occurs in five per cent of the patients within three years and in 17 per cent of the patients within seven years of their accident. Guttmann and Frankel (1966), however, observed such severe complications in only a very small percentage of their patients.

Formation of Stones. The formation of stones in the kidneys and in the efferent urinary ducts is one of the main dangers accompanying transverse lesions of the spinal cord. During World War II and in the first few years thereafter, renal calculi occurred in 30 to 50 per cent of paraplegics (Damanski, I963; Smith et al., 1969). The main factors causing stone formation are chronic urinary infection (especially infection caused by Bacterium proteus), alkaline urinary $\mathrm{pH}$, and, most important, urinary reflux; immobilisation and its effects also play a part (Comarr et al., I962; Damanski, 1963; Smith et al., 1969).

In the past 10 to 20 years, intensive prophylactic therapy, that is, intermittent catheterisation, urine acidification, prophylaxis against infection, forcing of fluids, and early mobilisation, has reduced what was formerly an alarmingly high rate to a value which is only slightly more than one per cent, which is the average 
frequency with which renal calculi appear in the general population in Western Europe and the United States (Boshamer, I96I; Sarre, 1967). The frequency of stone formation reported by the leading Anglo-American paraplegia centres is about two per cent (Damanski, I963; Guttmann \& Frankel, 1966; Smith et al., 1969). In the German literature, reviews have reported stone formation in up to 20 per cent of the patients (Büscher \& Federschmidt, I966; Stöhr, I968). Clinical studies of non-paraplysed patients with renal stones have shown that a large number of these people also have a chronic urinary tract infection, caused at least in part by Bacterium proteus (Aboulker \& Bernard, I97I).

Indications for Surgery. Every renal calculus, and especially every staghorn calculus, causes increasing damage to the renal parenchyma (Boshamer, I96I; Mauermayer, 1968). In the absence of contra-indications in non-paralysed patients, it is generally best to remove the stone as soon as possible. When the decision must be made whether or not to surgically remove a staghorn calculus, however, the possibility of serious intra- and post-operative complications must be considered. In particular, transparenchymal stone removal causes among other things, a rather considerable loss of parenchymal tissue (Mauermayer, 1968). The anatomical studies carried out by Sigel (I96I) revealed that a longitudinal incision (Hyrtl's line) causes a loss of I 5 to 23 per cent of the renal parenchyma. Applying this type of incision in animal experiments, Maddern (1967) determined that there was a 60 per cent loss of function in the kidney involved. In addition, as a result of various post-operative complications, it is often necessary to perform a secondary nephrectomy (Büscher, I96I). In order to reduce the number of such complications, other techniques have been recommended, such as transverse nephrotomy, where the parenchymal loss is reported to be smaller (Hasselbacher, 1960; Hiensch \& Schneider, 1969) or pyelocalicolithotomy in situ (Lutzeyer et al., 1970). There is a high rate of recurrences after surgical removal of renal stones (Boshamer, I96I; Büscher, I96I; Albrecht, I97I), but this number has been successfully decreased in neurologically healthy patients by means of intensive follow-up treatment (Büscher, I96I; Marshall et al., 1965; Strohmenger, I968; Kracht et al., 1970). Because of the adverse dynamic relationships and the disturbed calcium metabolism occurring in paralysed patients, calculi are even more likely to recur in these people, especially if a stone fragment still remains after surgery.

The surgical mortality rate for all patients (with or without spinal cord damage) with staghorn calculi averages about five per cent (Palivoda, I969; Albrecht, I971).

A comparison of the results of surgical and conservative treatment of staghorn calculi revealed that in spite of all the possible post-surgical complications, conservative treatment is less effective than surgery (Palivoda, I969; Arduino, I97I). As a result recently, most authors recommend surgery on neurologically healthy patients when it is at all possible (among others, Schmitz, I967; Strohmenger, 1968; Hiensch \& Schneider, 1969; Lutzeyer et al., 1970). Zielinsky, Luciak and Czopik (1970) reported recently that, with conservative treatment approximately two per cent of patients with staghorn calculi may be expected to develop squamous cell carcinoma of the kidney pelvis.

In the case of paraplegics and especially tetraplegics, however, various other factors must be considered when reviewing the indications for surgical removal 
of staghorn calculi. For example, the ventilatory capacity of tetraplegics is severely reduced (Silver, 1963). Because of the disturbed circulatory regulation it is important for the surgeon to control and check carefully intra-operative bleeding and for the anesthetist to control closely the cardiac and circulatory functions. Independent of the structural and functional changes in the kidneys and efferent urinary system of these patients, other pathological reactions affecting the entire body may occur in the functions governed by the autonomic nervous system (Guttmann, I966). One of our patients offers a good example of the various complications which can arise:

A 31-year-old tetraplegic (fracture of the sixth cervical vertebra following swimming accident, resulting in incomplete tetraplegia) developed a staghorn calculus which caused urinary retention and recurrent attacks of pyelonephritis; a left-sided nephrectomy was performed.

The following post-operative regulatory disturbances were observed:

(a) Urinary excretion: days I to 9 , approximately I 5 litres/day; days Io to I I, approximately 2.51 ./day; days $12-19$, about 5 to 5.51 ./day; from then on, 2.5 to 31 ./day.

(b) Gastro-intestinal function: daily bowel movement from the second post-operative day on; days 3 to 9 , isolated gastric atonicity. Between the third and sixth days, 2.5 to 3 litres of gastric juice were aspirated daily through a gastric tube; thereafter, the volume of gastric secretion decreased steadily until it was only $300 \mathrm{ml}$. on the ninth day, at which time the gastric tube was removed.

(c) Cardiac and circulatory regulation: the pulse rate was about $100 /$ minute until the I6th day; thereafter, about $80 /$ minute. The blood pressure showed variations, often abrupt, between $80 / 60 \mathrm{~mm}$. $\mathrm{Hg}$ and $\mathrm{I} 80 / 80 \mathrm{~mm}$. $\mathrm{Hg}$ until the third post-operative day; on the fourth and on the next few days the values were between $120 / 65$ and $150 / 70 \mathrm{~mm}$. $\mathrm{Hg}$.

(d) Temperature regulation: regular temperature measurement revealed no temperature elevation during the entire post-operative course, and leucocytes determined in the peripheral blood count were never above the normal range. Severe chills occured during the first few post-operative days as a result of central disregulation.

Liquid, electrolyte and acid-base relationships were carefully balanced. Serum urea and creatinine values were not elevated. The serum sodium and potassium levels were on the lower border of the normal range on only a few days, and serum chloride was generally on the upper border of normal or moderately elevated. The incision healed normally.

In our opinion, an absolute indication for surgery exists when, in the absence of other serious contra-indications, a staghorn calculus causes urinary retention. In such cases the patient nearly always suffers from a chronic inflammatory renal illness and the kidney may often be quickly destroyed, causing a life-threatening general reaction.

On the contrary, however, a paraplegic with a staghorn calculus which does not disturb urinary drainage and whose infection can be 'controlled' should be operated upon only under the most favourable conditions. Under conservative treatment, regular checks of renal function (including phenol red excretion and creatinine clearance) are necessary. In the past ten years a qualitative procedure, the so-called isotope-nephrography, has gained more and more importance in the determination of renal function. This method can detect decreases in function and obstructions in renal flow in the early stages and may be used to follow the course of disease without putting a heavy strain on the patient (Paeslack et al., I964). 
I04

Let us illustrate our opinion of the treatment of renal calculi, especially staghorn calculi in paraplegics, with a few case reports.

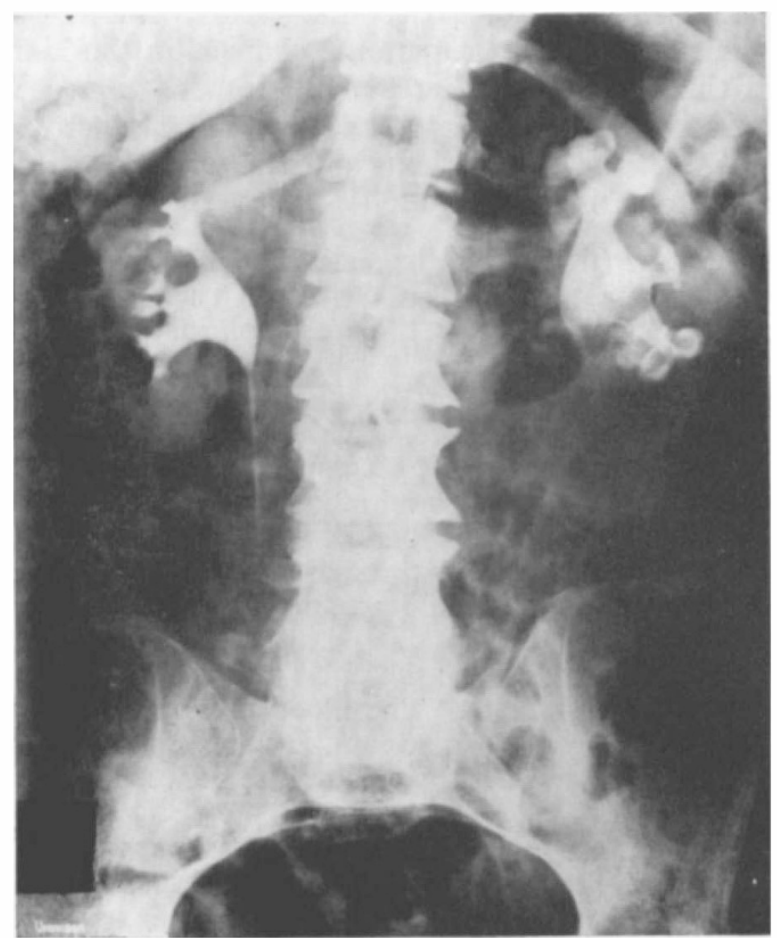

A

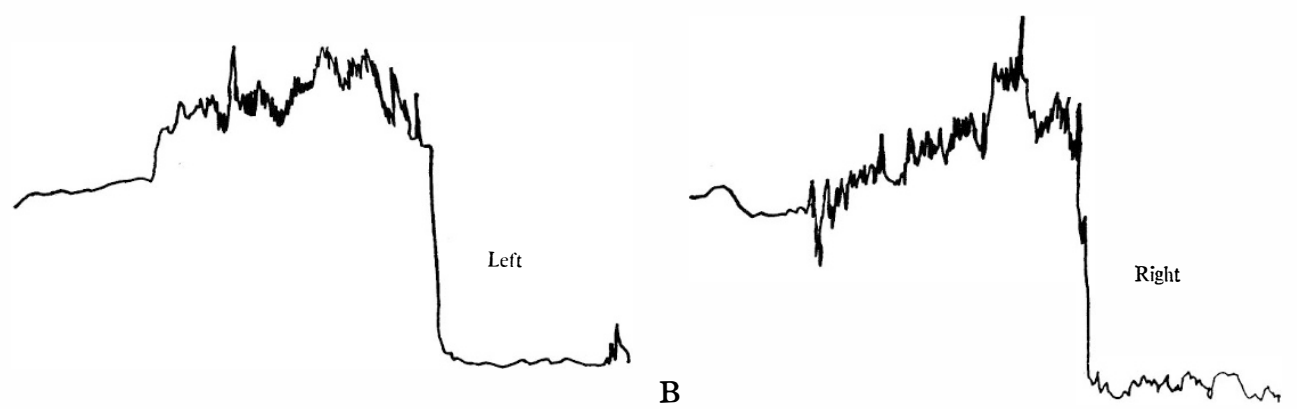

FIG. I

Patient H.-J. P.-A, Infusion pyelogram: left, staghorn calculus with destruction of the calyx ends; right, upper urinary tract unremarkable. B, IRG: left, moderate degree of parenchymal damage and flow obstruction; right, normal graph.

Case I. Patient H.-J. P., male, age 3I (1984/70).

1959. Fracture of the sixth cervical vertebra in a swimming accident, causing incomplete tetraplegia.

I964. Urethral fistula following decubitus ulcer. 
1969. Staghorn calculus on the left side. The isotope-nephrogram indicated good renal function on both sides without appreciable flow obstruction.

February 1970. X-ray showed all calyces of the left kidney to be deformed. Urinebound substances in serum were within normal limits. The blood sedimentation rate was on the upper border of normal, and the blood count was not abnormal.
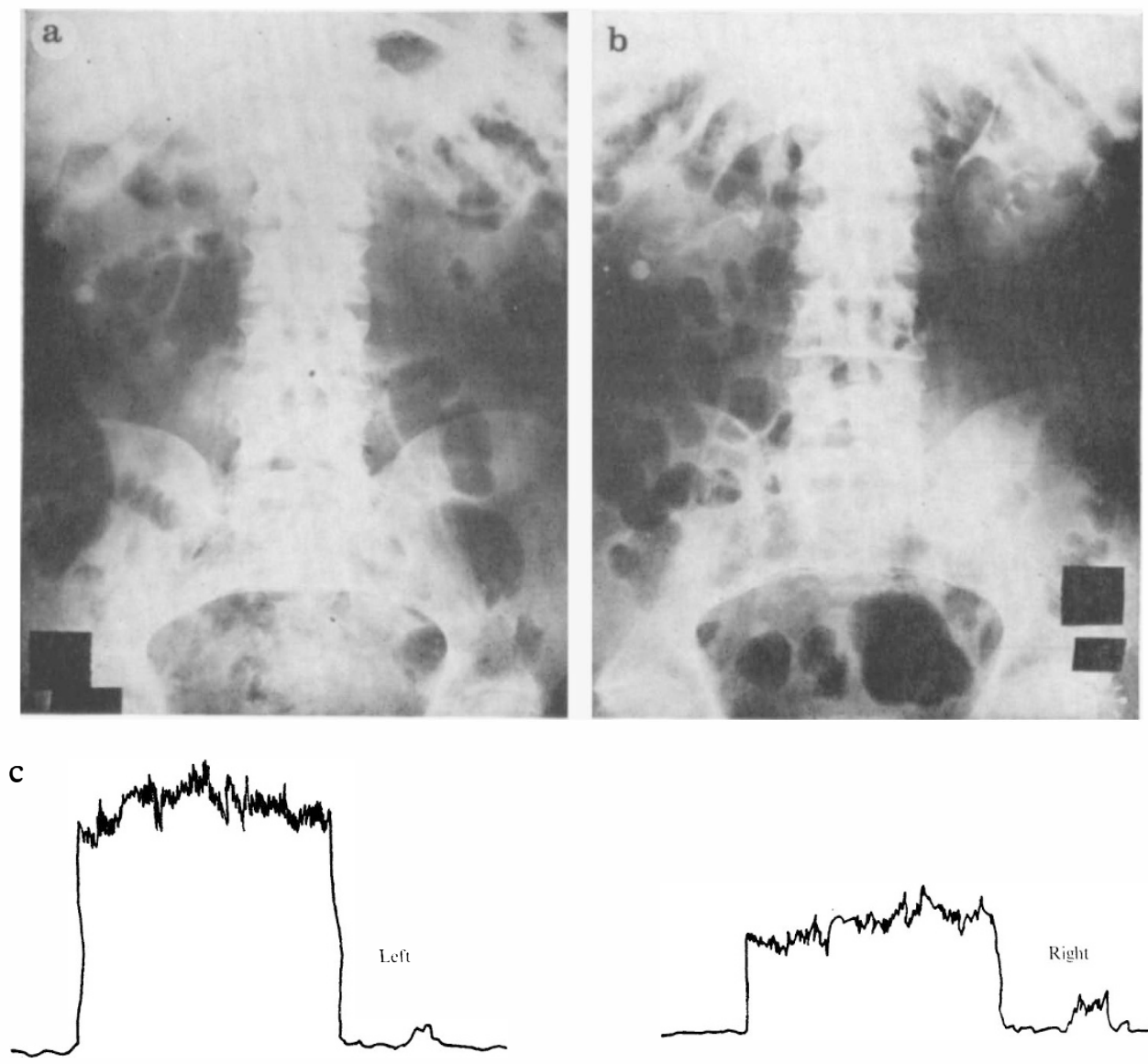

\section{FIG. 2}

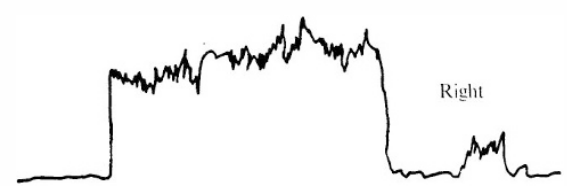

Patient G. L.-A, X-ray without contrast medium: right, staghorn calculus. B, Infusion pyelogram: right, no excretion; left, upper urinary tract normal. C, IRG: left, severe parenchymal damage; right, nonfunctioning kidney.

Phenol red excretion in urine was ten per cent after 15 minutes, 30 per cent after 30 minutes, 63 per cent after 60 minutes.

An isotope-nephrogram showed a slight decrease in renal function on the left side and a moderate obstruction of renal flow (fig. $\mathrm{I} b$ ). Urinalysis revealed a severe urinary tract infection. Long-term treatment with IturanR was continued.

September 1970. After the patient had suffered repeated attacks of septic fever due to recurrent pyelonephritis in the area of the left kidney, while the infusion-pyelography revealed approximately the same results as in February 1970 (fig. I $a$ ), nephrectomy was performed on the left side.

$$
12 / 2-H
$$


Case II. Patient G. L., male, age 34 (393/70).

I966. Luxation of the sixth cervical vertebra with complete tetraplegia. I967. Right-sided calyx stone.
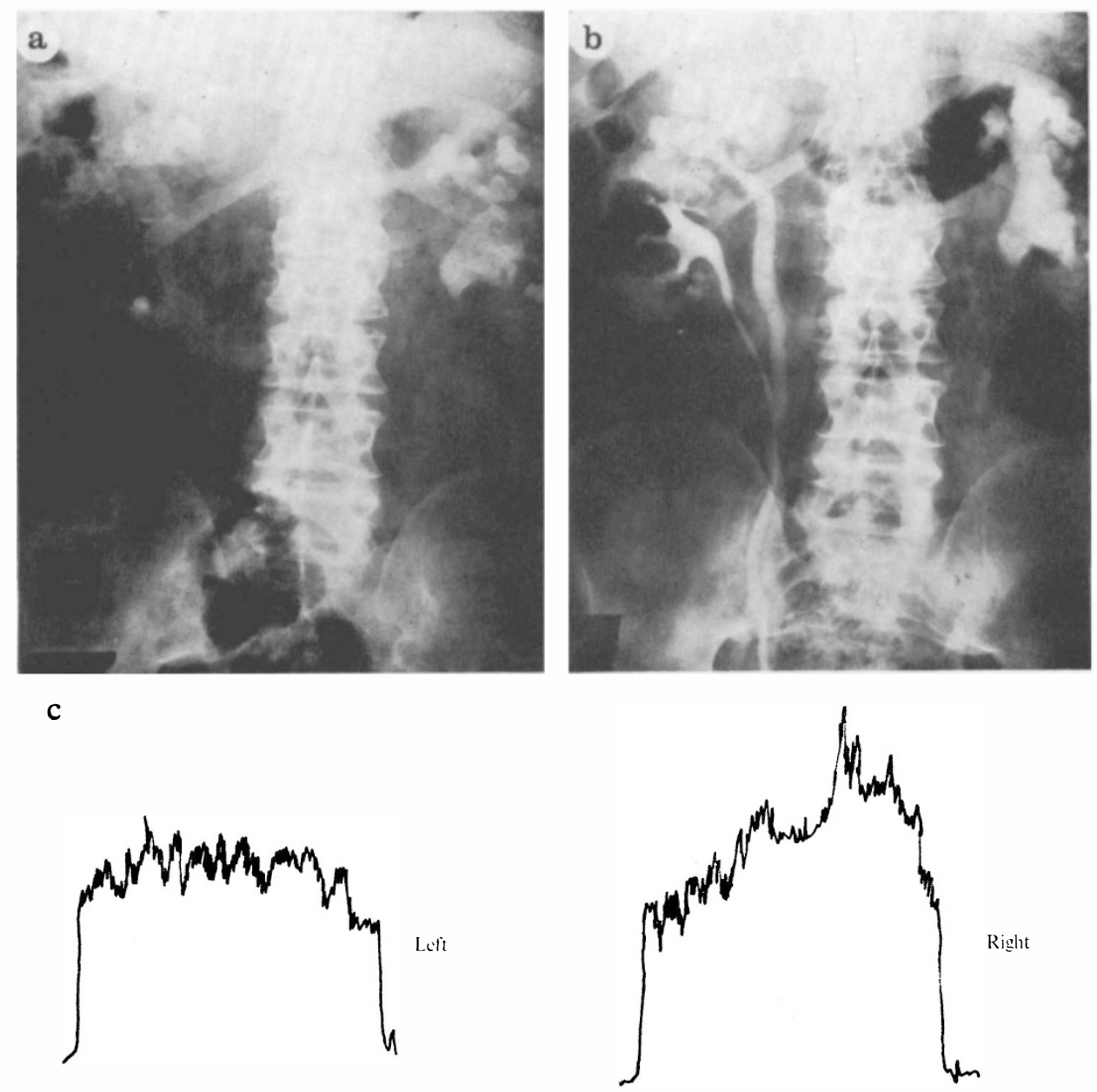

FIG. 3

Patient K. B.-A, X-ray without contrast medium: left, staghorn calculus; right, double kidney staghorn calculus in the upper part, calyx stone in lower portion. B, Infusion pyelogram: considerable destruction of the left kidney and of the upper portion of the right double kidney and in the calyx area of the lower portion. C, IRG: left, chronic backup of urine with moderate parenchymal damage; right, normal graph.

February 1970. Admitted to the hospital because of repeated attacks of dyspnoe, which continued to occur during the hospital stay. In addition, the patient experienced recurrent bouts of fever. In spite of potassium substition, the severe hypopotassemia could not be completely compensated. Urine-bound substances in serum were not elevated.

$\mathrm{X}$-ray showed the upper urinary tract to be normal, but a staghorn calculus was 
visible in the calyx and pelvis of the right kidney. No excretion of contrast medium could be observed on this side (figs. $2 a$ and $2 b$ ).

The isotope-nephrogram revealed severe parenchymal damage of the left kidney and an almost totally non-functioning kidney on the right side (fig. $3 c$ ). Because of the patient's poor general condition, surgery was not attempted. Under conservative treatment, the patient's condition improved enough so that he could return home.

a

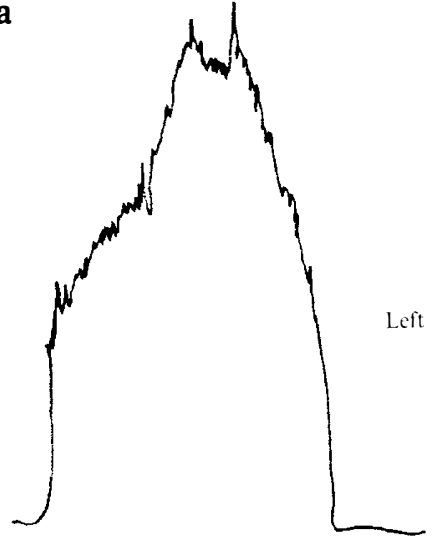

b

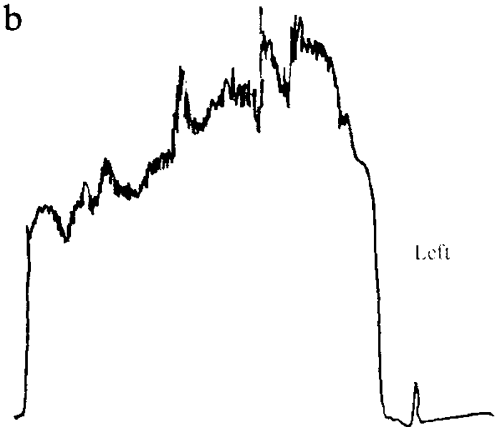

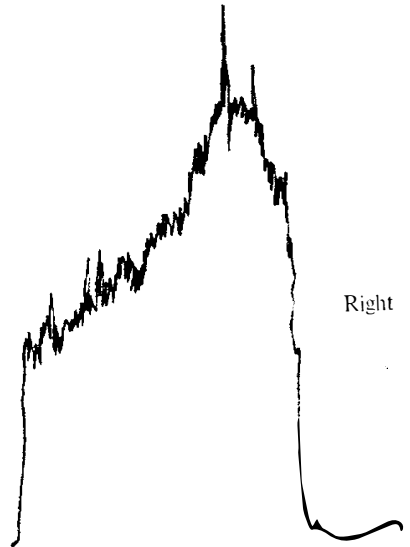

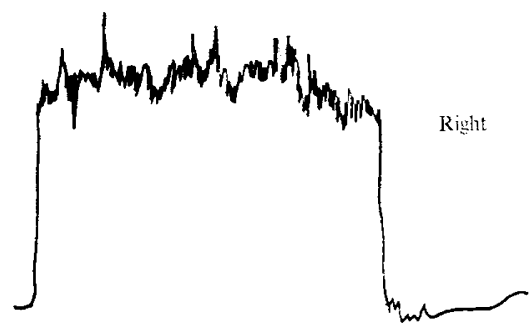

FIG. 4

Patient E. R.-A, IRG: normal graphs for both kidneys in the presence of a staghorn calculus on the right side. B, left, normal graph; right, chronic urinary backup and considerable parenchymal damage following nephrotomy.

Several months later, however, he was readmitted in poor condition and died a short time later due to cardiac failure and circulatory collapse.

Case III. Patient K. B., male, age 5I (4706/70).

1957. Fracture of the first lumbar vertebra, resulting in complete paraplegia.

1964. A renal cast was discovered in the left kidney and also in the upper part of the left-sided double kidney.

The patient was regularly examined and had no complaints, nor did he experience attacks of febrile pyelonephritis. In spite of a moderate urinary tract-infection, renal function remained practically unchanged over the years. X-rays taken in 1970 are 
shown in Figures $3 a$ and $3 b$; in addition, there was now a stone in the lower calyx of the lower part of the double kidney.

Isotope-nephrography in 1970 was similar to that in previous years, indicating a moderate degree of chronic urinary retention on the left side. Due to the functionally healthy lower part of the double right kidney, the graph of the right side was completely normal (fig. 3c).

Case IV. Patient R. E., female, age 36 (3016/70).

1966. Neurosurgical operation for presacral prolapsed disc which had caused incomplete paraplegia, bladder and colon disturbances, and a saddle-block paresthesia. No significant improvement was observed after surgery. The bladder had to be emptied by pressure on the lower abdomen.

1968. A staghorn calculus was diagnosed in the pelvis of the right kidney. It was at this point that we first saw the patient. X-ray revealed a staghorn calculus on the right side, accompanied by considerable pyelonephritic changes in all calyces. The upper urinary tracts on the left side were not abnormal; residual urine and reflux could not be demonstrated. Cystomanometry indicated a bladder capacity of $650 \mathrm{ml}$; the pressure on the bladder wall rose to only $10 \mathrm{~mm}$. $\mathrm{Hg}$ at maximum capacity.

Urine-bound substances and electrolyte balance were not abnormal, as were the blood count and sedimentation rate. Phenol-red excretion was 19 per cent after is minutes, 33 per cent after 30 minutes, and 72 per cent after 60 minutes. Urine culture revealed Enterococci, Klebsiella and Bacterium proteus. Long-term treatment of the urinary infection was started.

1970. The patient suffered recurrent renal colics on the right side and febrile pyelonephritic attacks. Upon hospital admission in April 1970, the serum urea and creatinine were normal, as was the electrolyte balance. The uric acid level was II $\cdot 9 \mathrm{mg}$. per cent; the creatinine clearance was $99 \mathrm{ml}$./minute. Phenol-red excretion was 26 per cent after I 5 minutes, 42 per cent after 30 minutes and 47 per cent after 60 minutes. Urine culture revealed an infection with Bacterium proteus.

The isotope-nephrogram yielded a normal graph on the left side (fig. 4a), and no significant reduction of the tubular phase nor any delay in emptying was noted on the right side. Because of recurrent symptoms since the beginning of the year, the staghorn calculus was removed by longitudinal nephrotomy on I4 April I970; unfortunately, three pea-sized calculi could not be removed.

Two months after being discharged from the hospital, the patient was re-admitted because of a urinary fistula in the area of the incision. The isotope-nephrogram showed chronic flow obstruction and severe loss of renal function (fig. $4 b$ ). Since the urine fistula did not respond to uretral catheter treatment, a right-sided nephrectomy was performed. The patient's urine was sterile upon dismissal from the hospital.

\section{SUMMARY}

Urinary tract infection, disturbances in calcium metabolism, and vesico-renal reflux are the main causes of calculus formation in the efferent urinary ducts in paraplegics.

Intermittent catheterisation should be an important measure in the early treatment of patients with spinal cord injury. A large number of cases of urinary infection and the resulting fatalities can be avoided when such therapy is correctly and skilfully carried out. During the illness, isotope-nephrography can play an important role in the determination of renal function. In Germany, the care and treatment of paraplegics is not yet as well organised as in the Anglo-Saxon countries, where the frequency of stone formation (kidney and bladder stones) in this group is about two per cent; we observed staghorn calculi in approximately 
eight per cent of our paraplegic patients. Of the 29 patients (23 paraplegics and six tetraplegics), all but one had received previous treatment elsewhere before being seen by us. All patients referred to us arrived with a severe mixed infection of the urinary tract and $B$. proteus were isolated from all urine specimens.

We do not feel that the surgical removal of staghorn calculi in paraplegics should be a main goal. On the contrary a staghorn calculus which does not obstruct renal flow and which is accompanied by a 'controllable' infection should be operated upon only under the most favourable conditions.

\section{RÉSUMÉ}

L'infection urinaire, les atteintes du métabolisme calcique et le reflux vésico-rénal sont considérés comme la principale cause de la formation de calculs dans les voies urinaires chez les paraplégiques. Les auteurs ne pensent pas que l'ablation chirurgicale d'un calcul coralliforme rénal chez les paraplégiques devrait être le principal but thérapeutique. Au contraire, un calcul qui n'obstrue pas la perméabilité des voies urinaires et qui s'accompagne d'une 'infection contrôlable', ne devrait être opéré que dans des conditions extrèmement favorables.

\section{ZUSAMMENFASSUNG}

Urininfektionen, Störungen im Calcium-Metabolismus und vesiko-renaler Reflux sind die Hauptursachen der Steinbildung beim querschnittsgelähmten Patienten. Intermittierende Katheterisation sollte eine wichtige Maßnahme in der Frühbehandlung von Patienten mit Rückenmarksverletzungen sein. Eine große Zahl von Fällen von Urininfektion mit fatalen Folgeerscheinungen kann vermieden werden, wenn diese Behandlung korrekt und sachgemäß ausgeführt wird. Die Isotopen-Nephrographie kann eine wichtige Rolle in der Beurteilung der Nierenfunktion spielen.

In Deutschland ist die Behandlung und Fürsorge von Spinalverletzten noch nicht so gut organisiert, verglichen mit den angelsächsischen Landern, wo die Häufigkeit von Nieren- und Blasensteinbildung nur $2 \%$ beträgt. Wir sahen bie approximativ $8 \%$ unserer Paraplegiker Ausgußste ine. Alle 29 Patienten, außer einem, hatten ihre frühere Behandlung in anderen Kliniken vor ihrer Aufnahme bei uns. Alle kamen zu uns mit schweren Mischinfektionen des Urintrakts. B. Proteus wurde in allen Urinproben isoliert.

Wir sind der Ansicht, daß die chirurgische Entfernung von Ausgußsteinen nicht das Hauptziel in der Behandlung von Paraplegikern ist. Im Gegenteil, ein Ausgußstein, der den renalen Ausfluß nicht blockiert und der mit einer 'kontrollierbaren' Infektion begleitet ist, sollte nur unter den günstigsten Vorbedingungen voroperiert werden.

\section{REFERENCES}

ABoulker, P. \& Bernard, E. (I97I). Phosphathaltige Nierenbeckenausgußsteine mit gramnegativer Begleitinfektion bei Traumen. Urologe, 10, 46.

AlbRECHT, K. F. (I97I). Langfristige Ergebnisse in der Chirurgie korallenförmiger Steine. Urologe, 10, 46.

ARduino, M. (I97I). Spätergenisse in der Chirurgie der Korallensteine. Urologe, I0, 46. Bors, E. (I957). Neurogenic bladder. Urol. Survey, 7, I77-250.

Boshamer, K. (I96I). Morphologie und Genese der Harnsteine. In Alken/Dix/Weyrauch/ Wildbold: Handbuch $d$. Urol., Bd X. Springer-Verlag.

BRitTen, D. \& RuEDAS, G. (I970). Über den Einfluß von Blasendruckerhöhungen auf die Nierenfunktion. Urol int. 25, 76-80.

BüsCHER, H.-K. (I966). Probleme der Erstversorgung Querschnitts-gelähmter. Verhandlungsber. Dtsch. Ges. Urol., 21. Tg., Düsseldorf, I965; Springer-Verlag.

BüsCHER, H.-K. (I96I). Therapie der Nieren-und Harnleitersteine. In Alken/Dix/ Weyrauch/Wildbold: Handbuch d. Urol. Band X. Springer-Verlag.

BüsCHER, H.-K. \& FEDERSCHMIDT, K. (I963). Probleme der urologischen Versorgung der Querschnittsgelähmten. Urologe, 2, 384-391.

BÜsCHER, H.-K. \& FEDERSCHMIDT, K. (I966). Die Bedeutung des vesico-ureteralen Refluxes. Fortschr. Med. 84, 315-319. 
ComarR, A.-E. (I96I). Chronic infection of the urinary tract among patients with spinal cord injuries. F. Urol. 85, 983-987.

Comarr, A.-E., Kawaichi, G. K. \& Bors, E. (1963). Renal calculosis of patients with traumatic cord lesion. F. Urol. 87, 647-656.

Dammanski, M. (1963). Stone desease in paraplegia. Paraplegia, I, I49-I56.

Frankel, H. (1969). Paraplegia, 7, I07.

Gibbon, N. O. V., Ross, J. C. \& SilveR, J. R. (1969). Changes in the upper urinary tract following various types of initial treatments. Paraplegia, 7, 63 .

GuttmanN, L. '(1966). Die Pathophysiologie und Behandlung der neurogenen Blase. Verhandlungsber. Dtsch. Ges. f. Urologie 21. Tg. Düsseldorf, I965. Springer-Verlag.

GuttmanN, L. \& Frankel, H. (I966).' The value of intermittent catheterisation in the early management of traumatic paraplegia and tetraplegia. Paraplegia, 4, 63-84.

HASSELBACHER, K. (1960). Nephrolithotomia transversa und partielle Nierenresektion. Z. Urol. 53, 656-662.

HiENSCH, E. \& SCHNEIDER, H. J. (I966). Organ-saving surgical treatment of renal staghorn calculi. Urology and Nephrology, I, I53-I66.

KaufmanN, J. \& Götze, H. (I968). Über die Bedeutung der Harnwegsinfektion für das Schicksal der Queschnittsgelähmten. Urologe, 7, 326-330.

Kollwitz, A.-A. (1963). Die Behandlung der querschnittsgelähmten Blase. Urologe, 2, 376-384.

KRACHT, H., Kollwitz, A.-A. \& LöHE, E. (1970). Ergebnisse der Rezidivprophylaxe bei Phosphatsteinen mit Aluminiumgelen. Urologe, 9, I75-I 78.

MAdDERn, J. P. (1967). Surgery of the staghorn calculus. Brit. F. Urol. 39, 237-275.

Lutzeyer, W., Lymberopoulos, S. \& Terhorst, B. (I970). Pyelolithotomia in situ. Urol. int. 25, 224.

MARChETTI, L. J. \& Ginick, P. (I970). A comparison of renal function in spinal cord injury patients with and without reflux. F. Urol. 104, 365-367.

Marshall, V. F., Lavengood, R. W. \& Kelly, D. (I965). Complete longitudinal nephrolithotomy and the Shorr regimen in the management of staghorn calculi. Ann. Surg. I62, 366-373.

MAUERMEYER, W. (1968). Möglichkeiten und Grenzen der organerhaltenden Steinchirurgie der Niere. Habilitationsschrift, TH München .

Paeslack, V., Roehl, F. \& ZUM WINKEL, K. (1964). Radio-isotope nephrographic studies in paraplegics. Paraplegia, 2, 246-252.

Palivoda, N. I. (1969). Vergleich der konservativen und operativen Therapie von Korallensteinen der Niere. Urologija i. nephrologija, 34, 3, 1969 ref. Z. Urol. 63, 5 I6.

SARRE, H. (1967). Nierenkrankheiten, G. Thieme-Verlag.

ScHmITZ, W. (I967). Klinische Erfahrungen bei 70 Fällen von Nierenbeckenausgußsteinen. Urologe, 6, 239-243.

Sigel, A. (I96I). Die anatomische Grundlage der partiellen Nephrektomie. Urol. int. II, I $54-165$.

SILVER, J. R. (1963). The oxygen cost of breathing in tetraplegic patients. Paraplegia, $\mathbf{I}$. 204-2I 4 .

Smith, P. H., Cook, J. B. \& Robertson, W. G. (1969). Stone formation in paraplegia. Paraplegia, 7, 77-85.

STÖHR, CHR. (I968). Verhütung von Steinbildungen in Harnsystem der Querschnittsgelähmten. Münch. med. Wschr. 170, 2308-2310.

Stoeprasius, E. (1970). Erste Ergebnisse nach l-jährigem Betrieb der neuen Station für Rückenmarksverletzte des Unfallkrhs. Murnau Med. Welt 2I, I900-1904.

Strohmenger, P. (I968). Pyelotomie mit transrenaler Dauerspülung als organerhaltende Behandlung von Korallensteinen der Niere. Z. Urol. 57, 905-912.

Zielinski, J., LUCiAK, M., CzopiK, J. (I970). Plattenepithelkrebs des Nierenbeckens infolge von Ausgußsteinen. Z. Urol. 63, 883-886. 